Elżbieta Ambrożej

\title{
PROPOSALS OF AMENDMENTS OF THE POLISH TAX LAW PROTECTING TAXPAYER'S RIGHTS
}

\section{Introduction}

Tax Law in Poland, which has been functioning as a separate branch of law for several years, can be characterized by a lack of stability and transparency. Numerous changes of tax regulations, often implemented in order to achieve expedient targets, including political ones, are fragmentary and chaotic. Besides, many norms lack a balance between the taxpayer's and tax agencies' rights and duties. The need to conduct a thorough reform of the tax system as well as the tax law has become more and more noticeable. At the same time, it is reckoned that conducting such a reform goes beyond the scope of the Ministry of Finance and requires involvement and cooperation of politicians, professionals and social forces. ${ }^{1}$

Conducting a deep and fundamental reform of the tax system is not possible in a short time therefore single solutions, which would eliminate wrong, unclear and inconsistent regulations and introduce new legal institutions required by both tax agencies and taxpayers, should be implemented.

During the last few months many attempts to change tax law regulations have been initiated. According to their authors they would contribute to the effective protection of taxpayers' rights. Special attention will be paid to bills on changing the Tax Ordinance Act. ${ }^{2}$

\footnotetext{
1 W. Nykiel, A. Mariański, Potrzeba zmian prawa podatkowego-reforma a bieżące udoskonalenia, „Przegląd Podatkowy" No. 52008 , pp. 8-10

2 The Act of $29^{\text {th }}$ August 1997 - Tax Ordinance Act (Consolidated text, Journal of Laws - Dz.U. 2005, No. 8, item 60 , with amendments; hereinafter referred to as: the OP)
} 


\section{Execution of tax body decisions}

In the Polish tax procedure, differently than in the administrative procedure, the rule of immediate execution of tax body decision is accepted. ${ }^{3}$ The suspension of the decision execution is treated by the $\mathrm{OP}$ as an exception to the accepted rule.

The differences between regulating the rules of the non-final decision execution in tax procedure and administrative procedure emerge from the fact that the tax procedure is characterized by a specific protection of a fiscal interest (the budget incomes are generated through taxes), whereas the administrative procedure is characterized by the protection of the procedure parties' interests. ${ }^{4}$

The solution accepted on the basis of the OP is quite controversial, and above all does not contribute to the protection of taxpayers' rights (interests). According to the OP, the decision of the first instance body should be executed within 14 days from the date it is served to a party. At the same time the party can appeal to the body of the higher instance through the body which issued the decision. The body relays the appeal alongside with the case files to the body of the higher instance within 14 days unless it annuls its own decision following so called auto-control course. The appellate body considers the case within 2 months (on pain of suspending the decision execution). The excess payment (with the interest) should be returned within 30 days starting on the day of issuing the decision about the change or suspension of the first instance body decision. It usually takes a few months from the execution of the tax decision to issuing the decision in the appellate course and returning the tax undue or higher than due, which is vital especially when we take into consideration an economic turnover. It should be noticed that the return of the tax undue (with interest) often cannot compensate the losses incurred due to the decision execution, which in appeal procedure was changed or annulled (for example limiting the range of the company's activity, the loss of reliability, closing down the company, dismissing the employees, and other).

In order to mitigate the effects of the immediate execution of the decision, and to protect the taxpayer's interests in case of a litigation between them and the tax body, the suspension of the tax decision is used.

In Poland we deal with a case of an obligatory suspension of the tax decision when the appellate body does not consider it within two months from the date of receiving it and when the appealed decision is not executed as a whole or partially.

3 Article $224 \S 1$ of the OP

4 Article 7 of the Act of $14^{\text {th }}$ June 1960 - Code of Administrative Procedure (Consolidated text: Journal of Laws Dz.U.2000, No. 98, item 1071 with amendments; hereinafter referred to as the K.p.a.) compels a duty upon the public administration agencies to take into consideration the public interest and the right interest of citizens in their procedures, 
In such a situation the execution of the decision is suspended ipso jure, within the limits of the claim which is the subject of the appeal. ${ }^{5}$

The OP regulations give the tax agencies the power to suspend the decision as a whole or its part ex officio or by the party's claim, but only in a case justified by an important interest of the party or public interest. ${ }^{6}$ What is important, the tax body's conclusion is based on its own recognition and therefore the reluctance to question its own decisions and to use this institution can be noticed.

Besides, the tax body sustains the execution of the appealed decision as a whole or partially till the date of the final decision or in case of lodging a complain before the administrative court until the decision of the administrative court comes into force, in case of a due provision for the discharge of the commitment. ${ }^{7}$

The necessity to introduce changes in the tax decisions executions in force has been lately widely discussed. As a result, some actions have been undertaken which aim at preparing the OP alteration. The work has been taken by MPs, the members of the Special Commission 'Friendly State' which deals with the issues connected with limiting bureaucracy and the Ministry of Finance simultaneously. ${ }^{8}$ The first bill, which was officially presented to Sejm, is a Deputies' bill on the change of the OP of $15^{\text {th }}$ April 2008. ${ }^{9}$ It posits introducing a system change in the tax procedure dealing with sustaining the execution of a decision. The bill suggests applying a solution from an administrative procedure, where on the basis of a principle, the decision before the appeal's expire date is not executed (Article $130 \S 1$ K.p.a) and lodging an appeal within the time limits defers the execution of the decision (Article $130 \S 2$ K.p.a). However, it does not concern the situation when the decision is on pain of an immediate execution and when the decision is a subject to an immediate execution ipso jure (Article $130 \S 4$ K.p.a). The appeal against the decision (except the cases mentioned above) is therefore an absolutely suspensive legal mean.

As a result of implementing the proposed changes in the OP, the decision of a tax body will not be executed until the final conclusion in the tax procedure (or - on the basis of the regulations of a fiscal control - in a control procedure by the

Article 225 of OP.

Ibid. Article $224 \S 2$

Ibid. Article 224 a

See: Biuletyn Komisji Sejmowych No. $732 / \mathrm{VI}$ on $4^{\text {th }}$ June 2008. According to its content, the Special Commission

'Friendly State', which deals with the issues connected with limiting bureaucracy, adopted a bill on changing the Tax Ordinacne Act with amendments and will soon be presented for approval by Sejm. The change introduces a rule that the tax decision will not be executed before the finale date of the appeal. Filing the appeal will defer the execution of the decision unless it will be on pain of an immediate execution or the execution of the decision will fully provide for the party's application notice before the time for the appeal is over.

Introducing the rule of the execution of final decisions appears also in the OP alteration, which is being prepared by the Public Finance Department of State.

9 Druk Sejmowy No. 596 
finance control agencies) is made. Only in particularly justified cases ${ }^{10}$, which are listed taxatively, the bill gives the tax bodies the right to classify the decision as on pain of an immediate execution. The decision which is not on pain of an immediate execution will not be executed until the decree of the administrative court is legalized. The bill indicates that the court, on request of a body (which is a party of the legal procedure) whose actions are the object of the appeal, will be empowered to classify the decision as on pain of an immediate execution if there is an important public interest involved, especially if the circumstances between issuing the decision and lodging the application in question suggest that the complainant is selling out his assets.

In regard to the decisions which were on pain of an immediate execution at the stage of the tax procedure, the complainant will be allowed to lodge an application before the court to defer the execution of the decision on the bases of existing regulations. They will also be in force in case when he court imposes the execution of a decision which was deferred earlier.

The bill not only defines the cases which can be on pain of an immediate execution but also lists those which cannot, though the case deals with those taxpayers who are from the 'unsafe' circuits. It is when the tax body will be in possession of a payback protection (e.g. mortgage, fiscal pledge, bank or insurance guarantee, bank guarantee or a bill backed by a bank, a cheque certified by a national bank of a cheque nominator, a pledge registered as shares emitted by the Treasury or the National Bank of Poland - according to their nominal value, deposit in cash) or when the taxpayer is a subject of an interpellation issued by the Minister of Finance.

It seems that the direction of the proposed changes is right, especially due to the taxpayer's right protection. One should abandon the philosophy which says: first take the money from the taxpayer, then analyze if it was right or wrong and pay back with the interest. Defining the rights and duties of the taxpayers only through securing the fiscal interest of the state is unfair and discriminatory. Maybe new solutions will cause an increased and not necessarily justified activity of taxpayers

10 The Bill on the change of Tax Ordinance, op cit:

'Art. 224a §1. The pain of an immediate execution can be applied to a decision, which can be appealed against, in the following cases:

1) the commitment amount defined or set by the decision exceeds 500.000 PLN,

2) the subject of the decision is a subject that is under closing down or bankruptcy,

3) there are enforcement proceedings towards the subject of the decision as far as the public and legal debt are concerned

4) the subject of the decision was convicted with legal validity for a fiscal crime or a crime against an economic turnover, in case of a legal person the condition refers to all the partners entitled to manage the corporation's affairs according to separate regulations,

5) the subject of the decision runs the enterprise for less than 12 months,

6) the subject of the decision has tax arrears, $\S 6$ excepted,

7) the decision concerns undisclosed income.' 
in lodging appeals against decisions, which not always would end with changing or annulling them, but it would certainly give a possibility to 'postpone' the deadline for the tax payment. It can be assumed that such a situation would not affect the state budget needs.

\section{'Tax Abolition'}

For the last few years, especially after the accession of Poland to the European Union, job migration mainly to those countries which opened their labour markets, such as Great Britain and Ireland, can be noticed. According to the Natural Persons Income Tax Act ${ }^{11}$, Poles whose tax residence remained in Poland and who are employed abroad are obliged to reckon their income tax, obtained not only in Poland but also abroad, in Poland. In order to avoid a double taxation, Poland has signed about 80 mutual international agreements. Those agreements for the prevention of a double taxation eliminate double taxation using one of the two methods: the credit method ${ }^{12}$ and the exemption with progression method..$^{13}$ The first method is less favourable for the taxpayers and means that the taxpayers have to pay extra in Poland although they have already paid the tax abroad. Such a situation causes that some Poles do not return to Poland only because of the fear that they would have to pay high taxes. The phenomenon is so worrying (it concerns mostly young and well-educated people) that there have been some legislative initiatives, such as tax abolition for the above mentioned group of taxpayers, taken.

A legislative initiative has been submitted to the Marshal by a group of MPs. It proposes authorising the Minister of Finance to issue a regulation abandoning the liability to taxation in case when the taxpayer is compelled to pay a tax, notwithstanding applying the method of avoiding a double taxation resulting from the Agreement for the prevention of a double taxation. ${ }^{14}$

The main aim of the proposed changes is to stop the process, which appears among the Poles working abroad, of abandoning the idea of returning to Poland. However, the proposed bill can receive some criticism.

11 The Act of $26^{\text {th }}$ July 1991 Natural Persons Income Tax (consolidated text: Journal of Laws - Dz. U. 2000, No. 14, item 176, with amendments), Article 27, item 8,9,9a

In the country of residence of the taxpayer the tax paid in the country where the income was received is allowed for in a whole or partially in the all-in income tax due. The tax paid abroad is returned only up to the amount which is equal to the tax due in the country of the income source, More on that topic: : L. Etel (edit.), Prawo podatkowe, Difin, Warsaw 2005, pp.119-120,

13 Ibid. pp 116-118, 'Eliminating a double taxation with the use of an exclusion with progression means that in the country of residence of the taxpayer the taxable income is reckoned not taking into consideration the income received abroad. As a consequence, the tax is levied only on the income which was received within the borders of that country. However, a special tax rate is used to assess the tax.'

14 A Deputies' Bill on the change of the Act of $6^{\text {th }}$ February 2008 Tax Ordinance, druk Sejmowy No. 549. The first reading took place on $12^{\text {th }}$ June 2008 , the bill was relegated to the Public Finance Commission, 
Firstly, is there really a need for such an alteration? After all, in the present state of law, the Minister of Finance can, in a form of a regulation, abandon as a whole or partially the collection of taxes, defining the tax type, period of time and a group of taxpayers. The regulation must be legitimised by a public interest or an important taxpayers' interest. ${ }^{15}$

Authorising the Minister of Finance to issue a regulation abandoning the liability to taxation also in case when the taxpayer is obliged to pay the tax in Poland (notwithstanding the method of avoiding a double taxation) may lead to violating the constitutional rule of equality before the law. The 'Tax Abolition' cannot favour those taxpayers who have a tax arrear in comparison to the persons who paid their taxes according to the law in force. ${ }^{16}$

According to the present legal state, the regulation on abandoning the tax collection as regards the taxpayers who run the enterprise (in the discussed case it considers a one-person enterprises) may mean a public aid as in the regulations of the Act on Public Aid Procedures. ${ }^{17}$ The attempt to provide aid for entrepreneurs has to be submitted to the European Commission in a form of an aid programme project defining the destination and conditions of the public aid.

It can also be questioned if, considering a wide circuit of the addressees of the proposed legal regulation, the rules and scope of abandoning tax collection should be in a form of a normative act such as a regulation or such as an Act. The proposed tax collection abandonment is in fact a tax relief, and so, according to the Article 217 of the Polish Constitution on granting tax relieves and exempts, it should be done in a form of an act. ${ }^{18}$

It seems that the alteration of the Act in the proposed form will not solve the problem of a double taxation of Poles in a systematic way and the goal set in the justification for the bill - encouraging Poles who work abroad to return to their motherland and restraining the process of deciding not to return to Poland. The reasons should be looked for in leaving a decision to issue the regulation in hands of the Minister of Finance, in the lack of defining the scope of the tax collection (will it refer to the whole tax or to a part of it), taxpayers groups which will be included in the tax relief, and also the time period which the relief considers.

\footnotetext{
15 Article $22 \S 1$ of the Tax Ordinance Act.

16 Compare: the opinion of the Polish Chamber of Commerce on the Deputies' Bill on the OP change, druk Sejmowy No. 549

17 The Act of $30^{\text {th }}$ April 2004 Public Aid Procedures (consolidated text, Journal of Laws - Dz.U. 2007, No. 59, item 404; with amendments)

18 More on this topic: C. Kosikowski, Konstytucyjność Ordynacji podatkowej, Państwo i Prawo, No. 2, 1998:

'The certificates to issue administrative acts included in Article $22 \S 1$ and 5, Art. 25, Art. $46 \S 3$ p. 2, Art. 48 § 3, Art. 58, Art. $67 \S 3$ and 4, Art., $79 \S 3$, Art. 85, Art. 89 and Art. $119 \S 2$ of Tax Ordinance (the Act of 1997 - Tax Ordinance) are not compliant with the Article 217 of the Constitution. The object of the regulation named in those regulations belongs to the sphere which comes within the tax act exclusivity therefore it cannot be a subject of a certificate to issue an administrative act.'
} 
An attempt to solve the problem of a double taxation was also presented in another Deputies' bill, the act on the change of the Natural Persons Income Tax Act. ${ }^{19}$ The authors of the alteration claim that 'the diversification of the taxpayers situations in accordance to the place of generating their income from the wage labour and due to a different order in agreements on preventing double taxation as for the methods of eliminating double taxation has no justification, furthermore, it rises serious doubts of constitutional nature (such a diversification violates the constitutional rights of equality in the eyes of law and social justice). ${ }^{20}$

The Bill introduces the possibility to choose the method of taxing incomes by all natural persons who earn their incomes in the countries that Poland has signed agreements to avoid a double taxation with (a credit method or an exemption with progression method) as far as the tax was levied on their incomes and the personal income tax was paid. The proposed regulation includes also a proposal to regulate the situation of those taxpayers who paid the tax according to the law in force. They will be allowed to apply for a return of the excess income tax with regard to the application of a more favourable taxation method.

It is also suggested that the taxpayers who in the years $2002-2006$ did not fulfil the obligation to reckon their taxable income according to the law in force would be allowed to reckon those arrears using a chosen method of avoiding double taxation regardless of which method of avoiding double taxation is included in the international agreement. The proceedings in fiscal crime or offence will not be initiated and those that have already been conducted will be discontinued and the interest for the delay will not be charged.

The presented bill rises many doubts. Especially the proposal of choosing the best method of eliminating a double taxation by the taxpayer when the international agreement clearly states such a method evokes criticism.

The Constitution of the Republic of Poland ${ }^{21}$ establishes the sources of law. According to its content ${ }^{22}$, a ratified international agreement, after being promulgated in the Journal of Laws of the Republic of Poland, becomes a part of a legal order and is directly applied unless its appliance depends on issuing a legal act. A ratified international agreement on a prior approval expressed in an act has priority over an act if the act does not correspond to the agreement.

Constitutional regulations do not allow introducing regulations in a form of an act which permits a free choice of a method eliminating double taxation in case when

\footnotetext{
19 The Bill on the change of the Act on Natural Persons Income Tax of 29th January 2008, druk Sejmowy No. 548 ,

20 The justification for the Bill on the change of the Act on Natural Persons Income Tax, druk Sejmowy No. 548

21 The Constitution of the Republic of Poland of $2^{\text {nd }}$ April 1997 (Journal of Laws - Dz. U. No. 78, item 48; with amendments)

22 Article 91 , part 1 and 2 of the Constitution
} 
the international agreement preventing double taxation clearly states such a method. The addressees of the act would have to use the method mentioned in the agreement anyway.

A negative but quite common phenomenon occurring in the tax law creation in Poland is making changes in tax legislation so to say incidentally while altering other acts, which often do not have anything in common with the tax law regulations. Those regulations, due to their frequent changes, are difficult to get to know. The discussed bill represents a similar case. The authors of the alteration propose introducing regulations to the Act on Natural Persons Income Tax, which deal, among others, with not initiating the legal proceedings in fiscal crimes or offences. Those regulations belong to the issue of the Act on Fiscal Penal $\mathrm{Code}^{23}$ and according to the legislative technique ${ }^{24}$, should not appear in the discussed bill because they concern the change of the Act on Natural Persons Income Tax and not the change of the Act on Fiscal Penal Code.

\section{Examples of other proposals of changes in the Tax Ordinance} Act

There will be a Deputies' bill on the change of the $\mathrm{OP}^{25}$ submitted to Sejm soon. It proposes the introduction of a three-month deadline for the post-tax control procedures to be initiated by taxation agencies in cases when the taxpayer did not rectify incorrectness revealed by the control. The above obligation will not be assumed in a case when the controlled taxpayers present explanations or the reservations about the protocol will be granted by the inspectors.

The proposed change should be appraised positively. The regulations in force do not specify the deadline of starting the tax procedure after the tax control was accomplished. The situation is unfavourable for the taxpayers who are anxiously waiting for the result of the procedure, which may start at an undefined time.

On $25^{\text {th }}$ April 2008 a bill on the amendments of the $\mathrm{OP}^{26}$ was submitted to the Sejm. It proposes repealing $\S 3$, art. $81 \mathrm{~b}$ of the $\mathrm{OP}^{27}$, which excludes the right to rectify

23 The Act of $10^{\text {th }}$ September 1999 - Fiscal Penal Code (consolidated text, Journal of Laws - Dz. U. 2007, No. 111, item 765; with amendments),

24 The Prime Minister's regulation of $20^{\text {th }}$ June 2002 regarding 'The legislative technique principles' (Journal of Laws - Dz. U. No. 100, item 908). According to the $\S 18$, part 1 of the annex to the above regulation, an object of an act is defined possibly the most briefly, but at the same time adequately informing about its content. According to part 2, while defining the object of an act the titles of other acts are not quoted, with an exception of an act changing or introducing another act, where the object of the act being changed or introduced is given. See: Biuletyn Sejmowy No. 732/VI. On the sitting on $4^{\text {th }}$ June 2008 the Special Commission 'Friendly State' for the issues connected with limiting bureaucracy, adopted the discussed bill on the change of the OP unanimously.

26 Druk Sejmowy No. 664,

27 As for the principle, the taxpayers, remitters and collectors can rectify the filed tax return. The rectification is by filing a rectified tax return along with a written justification for its reasons. The right to rectify the tax return can be 
the tax return after the tax control has finished in case of the goods and services tax. The Article $178 \S 1$ of the $\mathrm{OP}^{28}$ is also going to be changed. According to its content, the tax body, at every stage of the tax proceedings, is obliged to enable a party to look through the case files and to make notes, copies or photocopies. Nowadays it happens quite often that the tax bodies contest the taxpayers' right of the access to the case files after the first or second instance procedure and before lodging an appeal against the decision or a complaint before the administrative court. Such an attitude makes it quite difficult for the taxpayers to prepare means for a suit and to coach the charges and the demands correctly, which in consequence prevents them from claiming their rights.

Since $1^{\text {st }}$ January 2009 every taxpayer who is a subject to a tax proceeding will have a right to look through the case files, to make notes, copies or photocopies.

\section{Summary}

The proposals for the tax legislation amendments presented here, especially the ones concerning Tax Ordinance, seem indispensable. However, not always the method of conducting those changes suggested by the movers is the best one. It seems that the direction or the idea of changes itself is right, though. What is important, each of the presented alterations is on the stage of a bill which is to be submitted to Sejm or it has already been submitted but the procedure is not completed. Therefore, the process of the legislative proceeding in those cases requires undivided attention and one should hope that it will be finalised with the best possible result which will assure an effective protection of taxpayers' rights in Poland.

suspended for the time of the tax proceedings or tax control - in the ambit of those proceedings or control. The right continues after the tax control or tax proceedings are completed - in the ambit not included in the decision defining the amount of the tax liabilities, thus, for the time being it does not apply to the goods and services tax. 


\section{Streszczenie}

Niniejsze opracowanie przedstawia projekty ustaw (w szczególności dotyczące zmian w ustawie Ordynacja podatkowa), które przyczynić się mają do skuteczniejszej ochrony praw podatników. Analizie poddano projekty ustaw dotyczące: wprowadzenia do postępowania podatkowego zmiany w zakresie wykonalności nieostatecznej decyzji podatkowej (przed upływem terminu do wniesienia odwołania nie będzie ulegać wykonaniu); wprowadzenia trzymiesięcznego terminu na wszczęcie przez organy podatkowe postępowania podatkowego po kontroli podatkowej, w sytuacji gdy podatnik nie skorygował w całości nieprawidłowości ujawnionych w toku kontroli; przyznania podatnikowi prawa do skorygowania deklaracji podatkowej po zakończeniu kontroli podatkowej w zakresie podatku od towarów i usług; przyznania podatnikowi, wobec którego prowadzone będzie postępowanie podatkowe prawa do wglądu w akta sprawy, sporządzania z nich notatek, kopii lub odpisów w każdym czasie, wprowadzenia w Polsce „abolicji podatkowej”. 